\title{
A review of myrmecophilous mites of the family Microdispidae (Acari, Heterostigmatina) of Western Siberia
}

\author{
Alexander A. Khaustov' \\ I Tyumen State University, Tyumen, Russia \\ Corresponding author: Alexander A. Khaustov (alkhaustov@mail.ru) \\ Academic editor: Vladimir Pesic | Received 8 October 2014 | Accepted 27 October 2014 | Published 12 November 2014 \\ http://zoobank.org/58A02874-6BFB-4A80-8F07-F1113C7AF44E \\ Citation: Khaustov AA (2014) A review of myrmecophilous mites of the family Microdispidae (Acari, Heterostigmatina) \\ of Western Siberia. ZooKeys 454: 13-28. doi: 10.3897/zookeys.454.8709
}

\begin{abstract}
Five species of myrmecophilous microdispid mites (Acari: Microdispidae) are recorded from Western Siberia, Russia. Unguidispus lasii Kurosa, 1979, U. japonicus Kurosa, 1979, Caesarodispus minutus (Sevastianov, 1981), and C. samsinaki (Mahunka, 1967), comb. n. are reported from Russia for the first time. Unguidispus polyctenus (Sevastianov, 1969) and Caesarodispus samsinaki are redescribed. The keys to species of the genera Unguidispus Mahunka, 1970 and Caesarodispus Mahunka, 1977 are provided.
\end{abstract}

\section{Keywords}

Acari, Heterostigmatina, systematics, phoresy, ants, Western Siberia

\section{Introduction}

The family Microdispidae Cross, 1965 (Acari: Pygmephoroidea) includes 18 genera and about 115 described species (Hajiqanbar and Hosseininaveh 2014). All representatives from the genera Unguidispus Mahunka, 1970, Caesarodispus Mahunka, 1977, Myrmecodispus Cross, 1965, Reductodispus Mahunka, 1977, Perperipes Cross, 1965, and Glyphidomastax Cross, 1965 are associated with various ants (Hymenoptera: Formicidae) (Hajiqanbar and Hosseininaveh 2014). Most of microdispid mites are 
fungivorous, but the species from the genera Perperipes and Glyphidomastax, associated with army ants, probably feed on their larvae and/or eggs (Kaliszewski et al. 1995). During the study of myrmecophilous mites of Western Siberia we found five species of the family Microdispidae belonging to the genera Unguidispus Mahunka, 1970 and Caesarodispus Mahunka, 1977. The main goal of this paper is to redescribe the poorly known species Unguidispus polyctenus (Sevastianov, 1969) and Caesarodispus samsinaki (Mahunka, 1967), comb. n. and provide new records of myrmecophilous microdispid mites from Western Siberia, as well as the keys to world species of the genera Unguidispus and Caesarodispus.

\section{Materials and methods}

Mites were collected from ants or ant nests and mounted in Hoyer's medium. The terminology of idiosoma and legs follows Lindquist (1986); the nomenclature of subcapitular setae and the designation of cheliceral setae follow Grandjean (1944, 1947), respectively. The system of Pygmephoroidea follows Khaustov (2004, 2008). All measurements are given in micrometers $(\mu \mathrm{m})$. For leg chaetotaxy the number of solenidia is given in parentheses. The studied material is deposited in the mite collection of the Tyumen State University Museum of Zoology, Tyumen, Russia. SEM photographs were made with the aid of JEOL-JSM-6510LV SEM microscope.

\section{Systematics}

\section{Family Microdispidae Cross, 1965}

\section{Genus Unguidispus Mahunka, 1970}

Type species. Unguidispus stammeri Mahunka, 1970, by original designation.

Diagnosis. Female. Gnathosoma dorsally with 2 pairs of setae. Pharyngeal pumps 1 and 3 vestigial, pharyngeal pump 2 large, transversely striated. Prodorsum usually almost completely covered by tergite C. Cupules $i a$ and $i$ small, round. Two pairs of pseudanal setae present ( $p s_{2}$ absent). Posterior margin of posterior sternal plate entire. Leg I distinctly shorter than leg II. Tibiotarsus with well-developed claw; eupathidia $t c$ '- $t c$ " situated on clear pinnaculum; setae $s$ of tibiotarsus I present. Trochanter IV anterodorsally with short spine-like process.

The genus Unguidispus currently includes six species distributed in the Palaearctic region: U. stammeri, U. polyctenus (Sevastianov, 1969), U. contematosus Sevastianov, 1981, U. okumurai Kurosa, 1979, U. japonicus Kurosa, 1979, and U. lasii Kurosa, 1979. All species of the genus Unguidispus phoretic on ants of the genera Formica L. and Lasius Fabricius (Hymenoptera: Formicinae), or inhabit their nests (Hajiqanbar and Hosseininaveh 2014; Kurosa 1979). 


\section{Unguidispus polyctenus (Sevastianov, 1969)}

Figs 1-4

Piniphorus polyctenus Sevastianov, 1969, p. 68, fig. 2.

Xystrorostrum polyctenus: Mahunka 1970a: 165.

Unguidispus polyctenus: Mahunka 1970b: 282.

Redescription. Female Length of idiosoma 190-205, width 120-135.

Gnathosoma (Figs 1, 4E, 4F). Gnathosomal capsule beak-like, about 1.5 times longer than its width. Dorsally with two pairs of smooth subequal setae $(\operatorname{cha}, \operatorname{chb})$. Dorsal median apodeme absent. Ventral gnathosoma with one pair of subcapitular setae $m$ and a pair of oval pits situated posteromedial to bases of $m$. Palps with setae $d F e$ and $d G e$ dorsolaterally. Setae $d G e$ slightly longer than $d F e$. Ventral palpal structures not evident even on SEM photos (Fig 4F). Palps terminated with a relatively long and thin tibial claw (Fig 4F).

Idiosomal dorsum (Figs 1A, 4A). Prodorsum almost completely covered by anterior margin of tergite $\mathrm{C}$, with one pair of setae $s c_{2}$, one pair of clavate and weakly barbed trichobothria $s c_{1}$ with pointed apex, and one pair of large round stigmata. All dorsal shields smooth. All dorsal setae distinctly barbed; setae $d$ and $f$ blunt-ended, other dorsal setae pointed. Posterior margin of tergite $\mathrm{C}$ straight; posterior margin of tergite $\mathrm{H}$ with tongue-like elongation medially. Cupules $i$ a on tergite $\mathrm{D}$ and $i$ on tergite $\mathrm{H}$ small, round. Lateral shields covering lateral parts of tergite $\mathrm{D}$ with distinct sclerotized lines (Fig 4B). With a pair of arch-like structures anteriorly to setae $f$ and a pair of oblique ridges connected to bases of setae $e$ (Fig 4C). Length of dorsal setae: $s c_{2}$ 12-14, $c_{1} 35-38, c_{2} 40-42, d 36-38, e$ 44-45, $f 35-37, h_{1} 40-45, h_{2} 35-37$. Distances between setae: $s c_{2}-s c_{2} 37-40, c_{1}-c_{1} 47-50, c_{1}-c_{2} 22-24, d-d 41-43, e-f 18-20, f-f 35-38, h_{1}-h_{1}$ $19-21, h_{1}-h_{2} 18-21$.

Idiosomal venter (Figs 1B, 4D). All ventral plates smooth. All ventral setae pointed and barbed, except smooth $p s_{3}$. Apodemes 1 (ap1) weakly developed and joined with prosternal apodeme (appr); apodemes 2 (ap2) well developed, arch-like, fused with appr; prosternal and sejugal (apsej) apodemes well developed; apodemes 3 (ap3) well sclerotized. Apodemes 4 (ap4) well sclerotized and long, apodemes 5 absent. Posterior margin of posterior sternal plate slightly convex in middle part. Posterior margin of aggenital plate rounded. Anterior genital sclerite (ags) bell-like, posterior genital sclerite (pgs) very small, triangular. Length of ventral setae: $1 a$ 35-37, 1b 21-23, $2 a$ 33-36, 2b 36-40, $3 a$ 34-36, 3b 35-37, 3c 36-38, 4a 36-38, 4b 52-55, 4c 39-41, ps 24-26, ps ${ }_{3} 9-11$.

Legs (Figs 2-3, 4F). Leg I (Figs 2A, 4F) distinctly shorter and thinner than leg II. Setal formula: 1-3-4-16(4). Tibiotarsus not thickened, with well-developed terminal claw situated on distinct pretarsus, tip of the claw thin. Length of solenidia $\omega_{1} 11-12=$ $\omega_{2} 11-12>\varphi_{1} 6-7=\varphi_{2} 6-7 ; \omega_{1}$ and $\omega_{2}$ finger-shaped, $\varphi_{2}$ baculiform, $\varphi_{1}$ clavate. Setae $(u)$ fused into structure opposing to tarsal claw. Leg II (Fig 2B). Setal formula: 1-3-3-4(1)6(1). Tarsus with sickle-like, padded claws and large empodium. Solenidion $\omega$ 9-10, finger-shaped, solenidion $\varphi 3-4$ weakly clavate. Seta $d F e$ distinctly blunt-ended. Leg III 


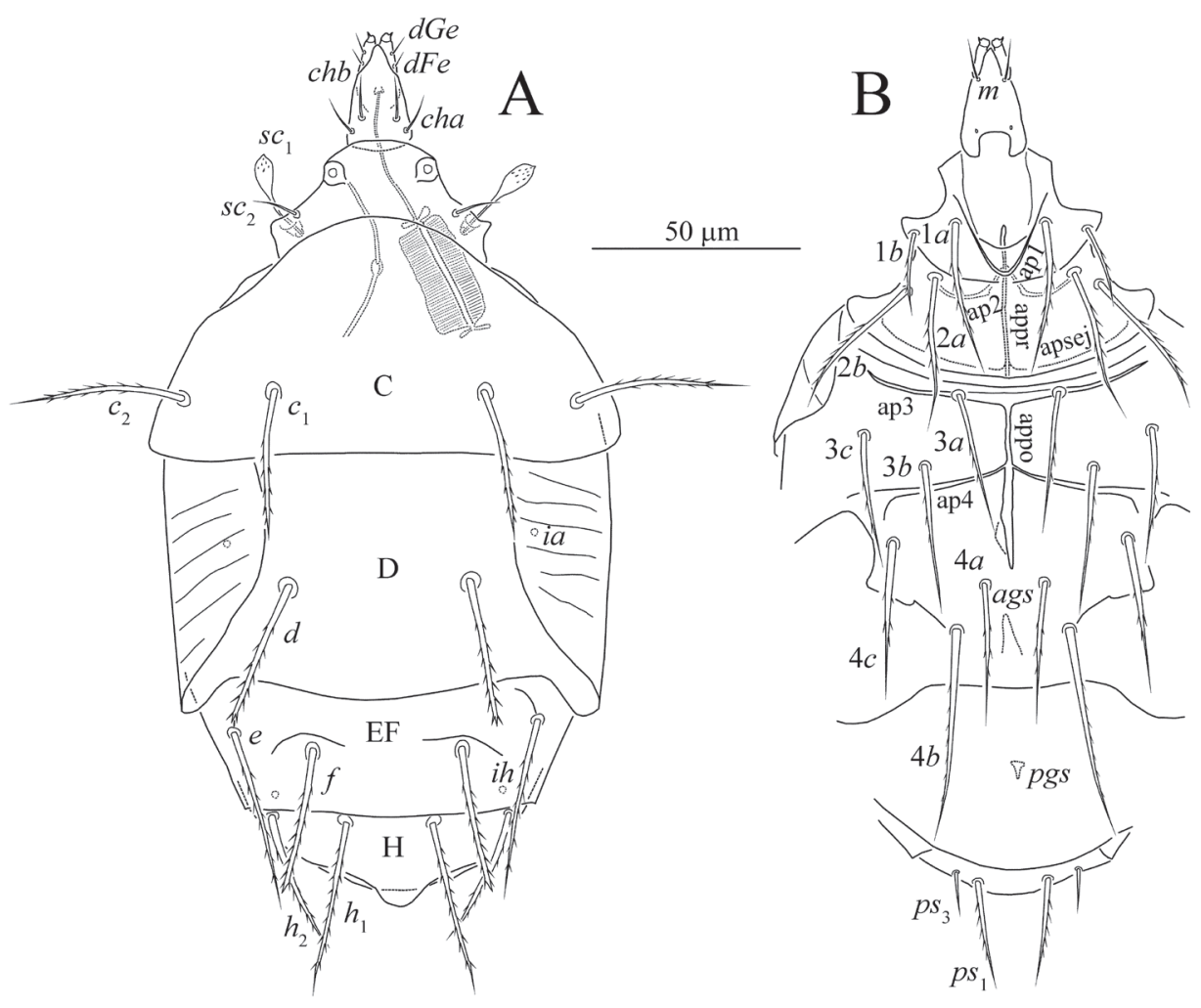

Figure I. Unguidispus polyctenus (Sevastianov, 1969), female: A dorsum of the body B venter of the body.

(Fig 3A). Setal formula: 1-2-2-4(1)-6. Claws of same shape as on tarsus II. Solenidion $\varphi$ 3-4 weakly clavate. Seta $d F e$ distinctly blunt-ended. Leg IV (Fig 3B). Setal formula: 1-2-1-4(1)-6. Tarsus long and thin, pretarsus short, with two small simple claws and small empodium. Solenidion $\varphi 3-4$, weakly clavate. Seta $d F e$ distinctly blunt-ended.

Male and larva unknown.

Material examined. Eight female paratypes, UKRAINE, Khmelnitsk Province, vicinity of settlement Chemerovtsy, on ants Formica polyctena Forster, 23 July 1966, coll. V.D. Sevastianov; 3 females, RUSSIA: Tyumen Province, vicinity of Tyumen, $57^{\circ} 04^{\prime} 03^{\prime \prime N}, 65^{\circ} 04^{\prime} 12^{\prime \prime E}$, on ants Formica rufa L., 17 August 2014, coll. A.A. Khaustov; 15 females, RUSSIA, Tyumen Province, vicinity of Tyumen, $57^{\circ} 13^{\prime} 43.6^{\prime \prime} \mathrm{N}$, 65'28'28.4"E, on ants Formica polyctena, 14 September 2014, coll. A.A. Khaustov.

Distribution and hosts. This species was described from Western Ukraine from ants Formica polyctena Forster (Sevastianov 1969). It was also recorded in northwestern Russia (Sevastianov 1978), Austria (Mahunka 1970b) from ants Formica rufa L., and in Hungary from ant nest (Mahunka 1987).

Remarks. Sevastianov (1969) placed this species in the genus Piniphorus Sevastianov, 1969. Mahunka (1970a) transferred it to Xystrorostrum Mahunka, 1968 


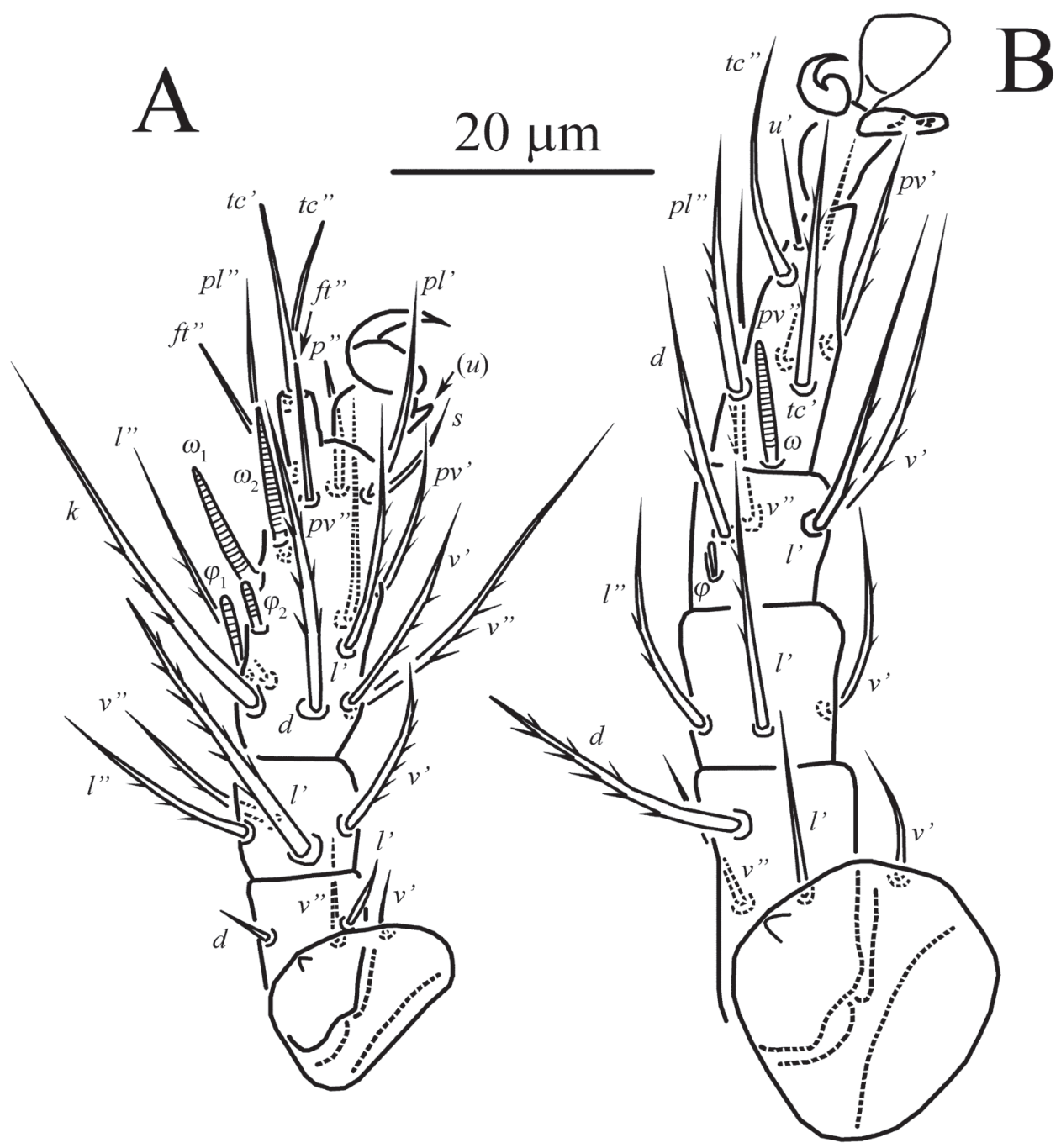

Figure 2. Unguidispus polyctenus (Sevastianov, 1969), female: A leg I B leg II.

(Neopygmephoridae) which he considered as a senior synonym of Piniphorus. The same year Mahunka (1970b) moved this species to the microdispid genus Unguidispus Mahunka, 1970. In spite of this, Sevastianov (1978) retained it in the neopygmephorid genus Xystrorostrum.

The original description of $U$. polyctenus of Sevastianov (1969) is incomplete, thus I made a redescription of this species. The present redescription of $U$. polyctenus is based mainly on material from Western Siberia. The female paratypes available for this study are found in bad condition, yet sufficient to prove their identity with mite specimens from Western Siberia. 


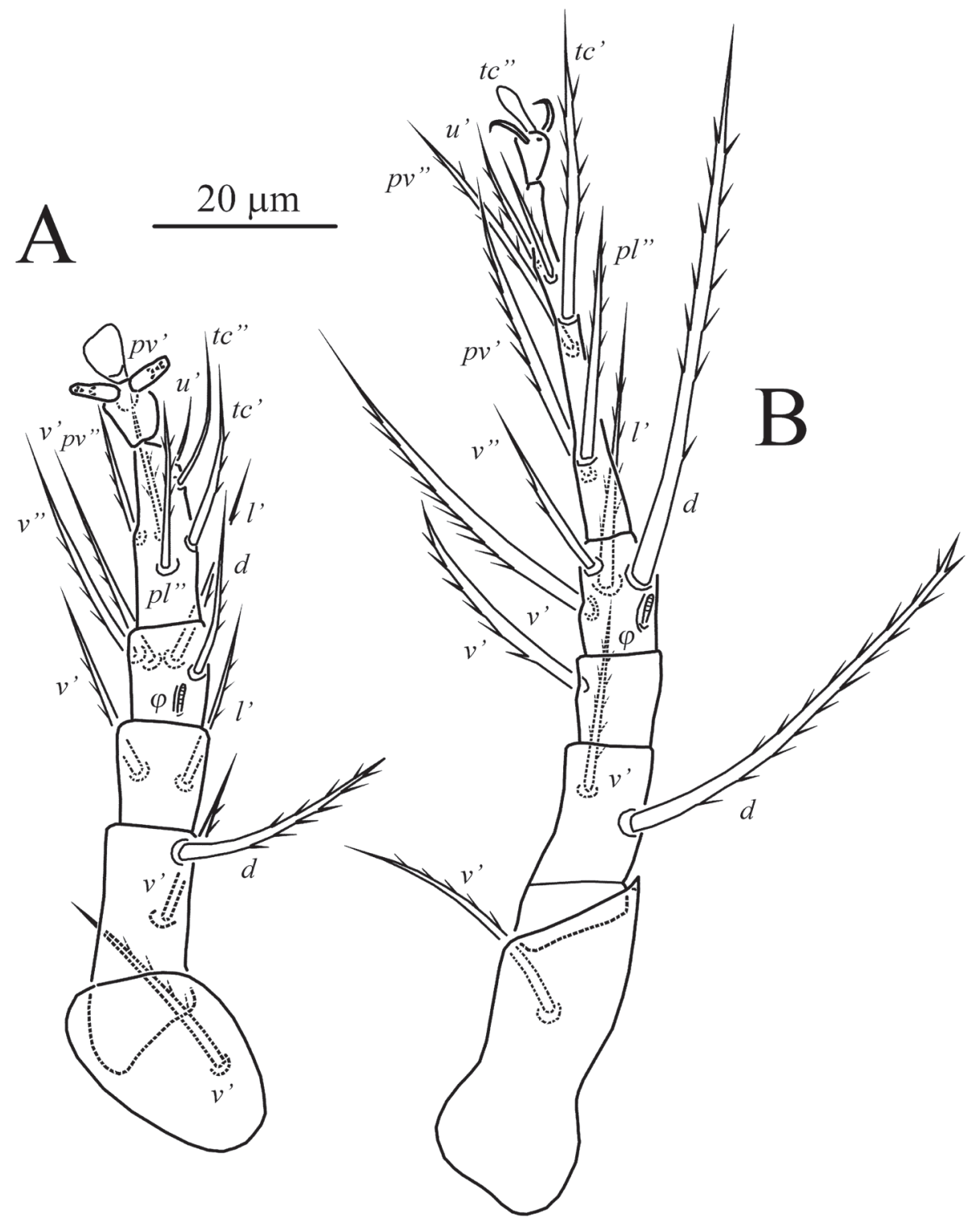

Figure 3. Unguidispus polyctenus (Sevastianov, 1969), female: A leg III B leg IV.

\section{Unguidispus lasii Kurosa, 1979}

Unguidispus lasii Kurosa, 1979, p. 66, figs 5-6.

Material examined. Six females, RUSSIA: Tyumen Province, vicinity of Tyumen, $57^{\circ} 04^{\prime} 03^{\prime \prime} \mathrm{N}, 65^{\circ} 04^{\prime} 12^{\prime \prime} \mathrm{E}$, on ants Lasius niger L., 17 August 2014, coll. V.M. 


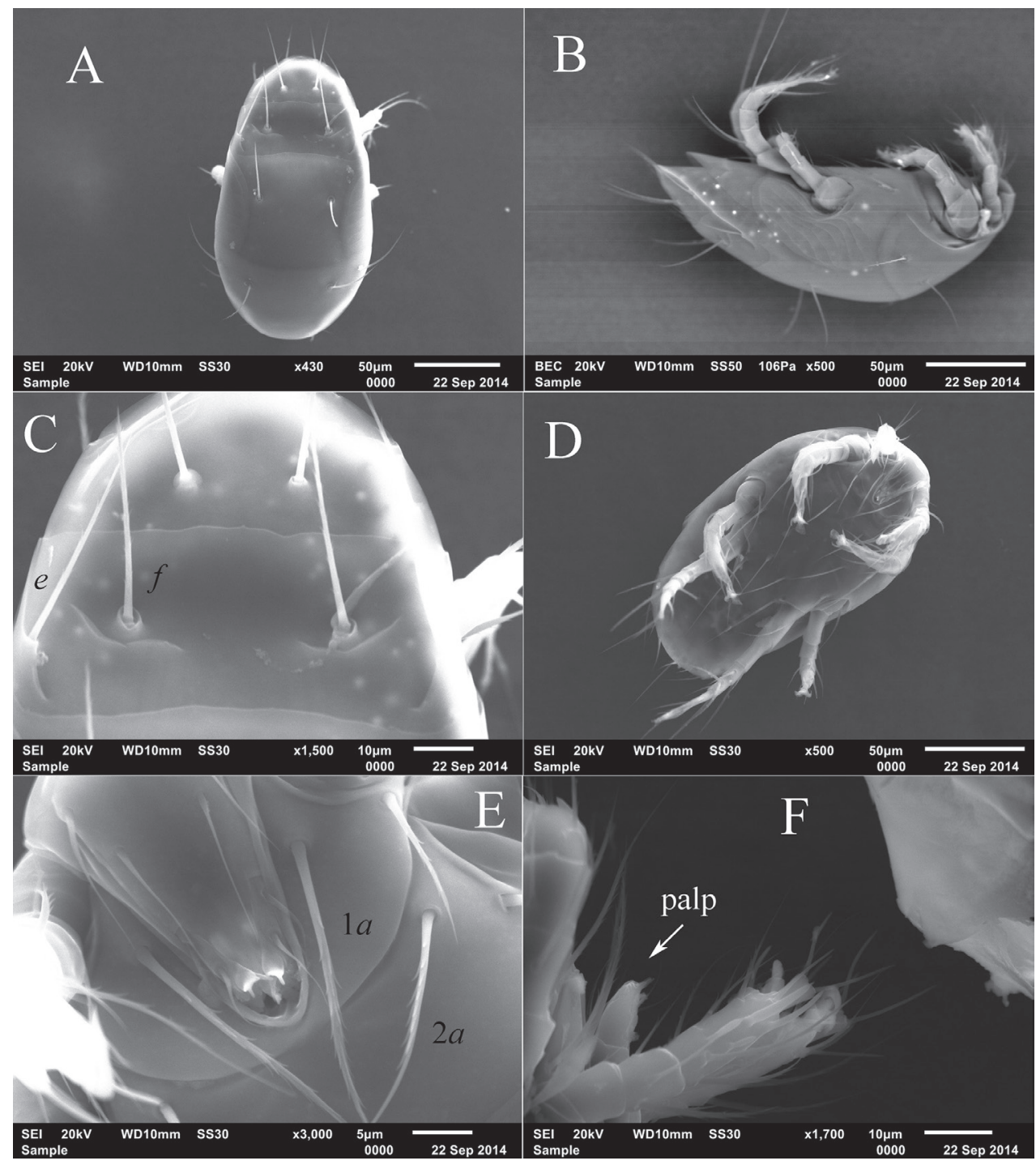

Figure 4. Unguidispus polyctenus (Sevastianov, 1969), female, SEM photos: A dorsum of the body B lateral view of the body $\mathbf{C}$ tergites $\mathrm{EF}$ and $\mathrm{H} \mathbf{D}$ venter of the body $\mathbf{E}$ gnathosomal capsule $\mathbf{F}$ legs I and distal part of gnathosoma laterally.

Salavatulin; 5 females, Russia: Tyumen Province, vicinity of Tyumen, 5709'55"N, 65'27'32"E, on ants Lasius niger, 31 August 2014, coll. A.A. Khaustov.

This species was described from Japan where it was found in the nests of ants Lasius niger and L. hayashi Yamauchi and Hayashida (Kurosa 1979). I recorded phoresy of this species on Lasius niger in Western Siberia. This is a new record for the fauna of Russia. 


\section{Unguidispus japonicus Kurosa, 1979}

Unguidispus japonicus Kurosa, 1979, p. 64, figs 1-2.

Material examined. Five females, RUSSIA: Tyumen Province, vicinity of Tyumen, $57^{\circ} 04^{\prime} 03^{\prime \prime N}, 65^{\circ} 04^{\prime} 12 " \mathrm{E}$, on ants Lasius niger, 17 August 2014, coll. V.M. Salavatulin. 2 females, RUSSIA: Tyumen Province, vicinity of Tyumen, $57^{\circ} 09^{\prime} 55^{\prime \prime} \mathrm{N}, 65^{\circ} 27^{\prime} 32$ "E, on ants Lasius niger, 31 August 2014, coll. A.A. Khaustov.

This species was described from Japan from the nests of ants Lasius niger (Kurosa 1979). I recorded phoresy of this species on Lasius niger in Western Siberia. This is a new record for the fauna of Russia.

\section{Key to world species of the genus Unguidispus (females)}

1 All dorsal hysterosomal setae unmodified 2

- $\quad$ At least setae on tergites $\mathrm{C}$ and D flattened, widened distally, and heavily

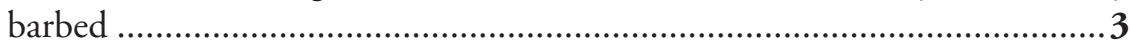

2 Setae $c_{1}, d$, and $f$ thin and smooth, without arch-like ridges anteriorly to setae $f$................................ okumurai Kurosa, 1979. Japan. On Lasius hayashi

- $\quad$ All dorsal hysterosomal setae strongly barbed, with arch-like ridges anteriorly to setae $f$.................................................................. polyctenus (Sevastianov, 1969). Ukraine, Austria, Hungary, Russia. On Formica rufa, F. polyctena

3 Setae $h_{1}$ flattened, widened distally and barbed ............................................ 4

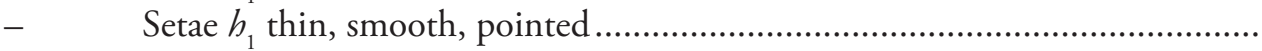
..U. contematosus Sevastianov, 1981. Ukraine. On Lasius fuliginosus

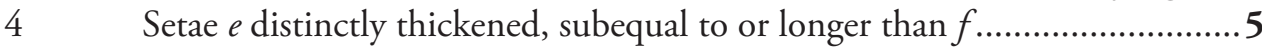

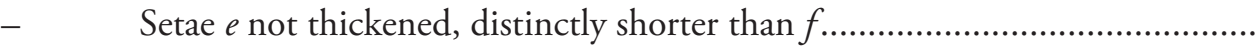
U. lasii Kurosa, 1979. Japan, Russia. On Lasius niger, L. hayashi Setae $h_{2}$ pointed, setae $d$ distinctly thicker than $f$, trichobothria spherical...... U. japonicas Kurosa, 1979. Japan, Russia. On Lasius niger - Setae $h_{2}$ widened distally, setae $d$ as thick as $f$, trichobothria pointed distally..... U. stammeri Mahunka, 1970. Hungary. In ant nest.

\section{Genus Caesarodispus Mahunka, 1977}

Type species. Caesarodispus gaius Mahunka, 1977, by original designation.

Diagnosis. Female. Gnathosoma dorsally with two pairs of setae. Pharyngeal pumps 1 and 3 vestigial, pharyngeal pump 2 large, transversely striated. Prodorsum usually almost completely covered by tergite C. Cupules ia and ih small, usually round. Two pairs of pseudanal setae ( $p s_{2}$ absent). Posterior margin of posterior sternal plate entire. Leg I distinctly shorter than leg II. Tibiotarsus without claw; pinnaculum 
absent; setae $s$ of tibiotarsus I present. Trochanter IV anterodorsally without spinelike process.

The genus Caesarodispus currently includes nine species distributed in the Holarctic region: C. gaius, C. samsinaki (Mahunka, 1967), comb. n., C. minutus (Sevastianov, 1981), C. acuminatus (Sevastianov, 1981), C. klepzigi Khaustov \& Moser, 2008, C. pusillus Khaustov, 2009, C. brevipes Mahunka, 1986, C. modestus (Berlese, 1903), and C. shandizensis Loghmani \& Hajiqanbar, 2014. All species of the genus Caesarodispus phoretic on various ants, or inhabit their nests. Loghmani et al. (2014) discussed distribution and host specificity of the genus Caesarodispus and provided key to eight species.

\section{Caesarodispus samsinaki (Mahunka, 1967), comb. n.}

Figs 5-7

Pygmephorus samsinaki Mahunka, 1967, p. 241, fig. 1.

Brennandania samsinaki: Mahunka 1972: 82.

Petalomium samsinaki: Sevastianov 1978: 37.

Redescription. Female. Length of idiosoma 220, width 135. Gnathosoma (Figs 5-6). Gnathosomal capsule about as long as its width. Dorsally with two pairs of smooth setae $(c h a, c h b)$. Setae cha slightly longer than $c h b$. Dorsal median apodeme absent. Ventral gnathosoma with one pair of subcapitular setae $m$ and a pair of oval pits situated posteromedial to bases of $m$. Palps short, with setae $d F e$ and $d G e$ dorsolaterally. Setae $d G e$ slightly longer than $d F e$. Ventrally with tiny solenidion and accessory setigenous structure. Palps terminated with a relatively short and thick tibial claw. Palpal tibiotarsus laterally with small triangular translucent process. Pharyngeal pumps 1 and 3 small, vestigial; pharyngeal pumps II large, transversely striated (Fig. 5A).

Idiosomal dorsum (Fig 5A). Tergite C covering only posterior part of prodorsum, which bears one pair of setae $s c_{2}$, one pair of spherical and weakly barbed trichobothria $s c_{1}$ and one pair of oval stigmata. Prodorsal shield with sparsely distributed small dimples. All hysterosomal tergites distinctly reticulated and with sparsely distributed small dimples. All dorsal setae lanceolate, sparsely barbed. Posterior margin of tergite C straight; posterior margin of tergite $\mathrm{H}$ with tongue-like elongation medially. Cupules $i a$ on tergite $\mathrm{D}$ and $i h$ on tergite $\mathrm{H}$ very small, round. Length of dorsal setae: $s c_{2} 32, c_{1}$ 42, $c_{2} 44, d 58, e$ 47, $f 50, h_{1} 54, h_{2}$ 46. Distances between setae: $s c_{2}-s c_{2} 43, c_{1}-c_{1} 35$, $c_{1}-c_{2} 24, d-d 31, e-f 25, f-f 30, h_{1}-h_{1} 29, h_{1}-h_{2} 19$.

Idiosomal venter (Fig 5B). All ventral plates with small dimples. Posterior part of posterior sternal plate and aggenital plate reticulated. All ventral setae pointed and barbed. Ap1 well-developed and joined with appr; ap2 thin, arch-like, fused with appr; appr and apsej well developed; ap3 indistinct. Ap4 well sclerotized and long, apodemes 5 absent. Posterior margin of posterior sternal plate slightly convex in middle part. Posterior margin of aggenital plate rounded. Ags bell-like, pgs elongate, subtriangular. 


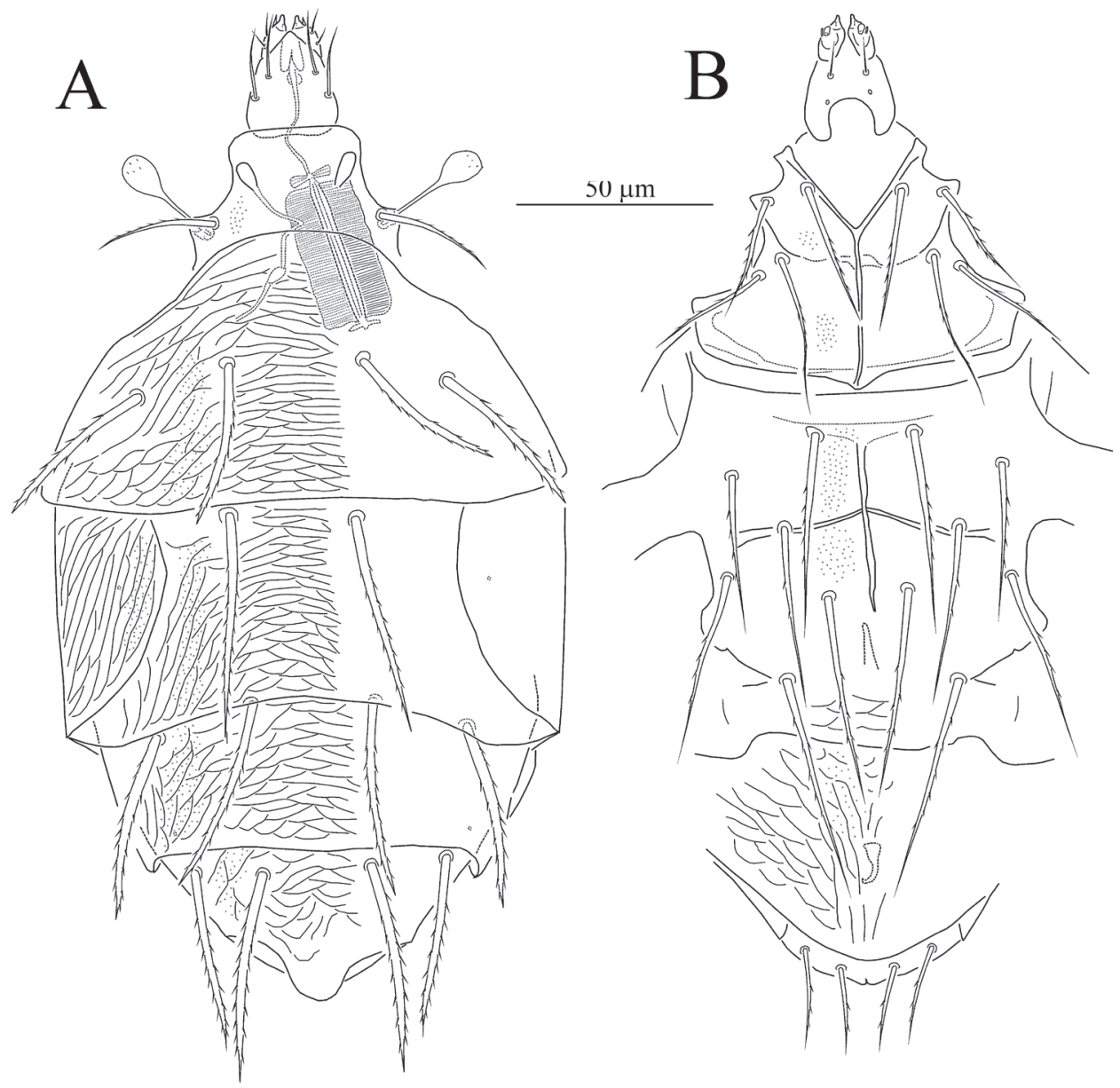

Figure 5. Caesarodispus samsinaki (Mahunka, 1967), comb. n., female: A dorsum of the body B venter of the body.

Length of ventral setae: $1 a 35,1 b 32,2 a 42,2 b 39,3 a 52,3 b 47,3 c 40,4 a 54,4 b 60$, $4 c 47, p s_{1} 23, p s_{3} 24$.

Legs (Figs 6-7). Leg I (Fig 6A) distinctly shorter and thinner than leg II. Setal formula: 1-3-4-16(3). Tibiotarsus not thickened, cylindrical. Length of solenidia $\omega_{1} 11>$ $\varphi_{1} 5<\varphi_{2} 10 ; \omega_{1}$ and $\varphi_{2}$ finger-shaped, $\varphi_{1}$ clavate, solenidion $\omega_{2}$ absent. Seta $k$ very long, slightly longer than combined genu and tibiotarsus I. Leg II (Fig 6B). Setal formula: 1-2-3-4(1)-6(1). Tarsus with sickle-like, padded claws and large empodium. Solenidion $\omega 8$, finger-shaped, solenidion $\varphi 4$ weakly clavate. Setae $v$ " of femur II absent. Leg III (Fig 7A). Setal formula: 1-2-2-4(1)-6. Claws of same shape as on tarsus II. Solenidion $\varphi 4$ weakly clavate. Seta $d F e$ blunt-ended. Leg IV (Fig 7B). Setal formula: $1-2-1-4(1)-6$. Tarsus long and thin, pretarsus short, with two small simple claws and small empodium. Solenidion $\varphi$, weakly clavate. Seta $d F e$ distinctly blunt-ended. 

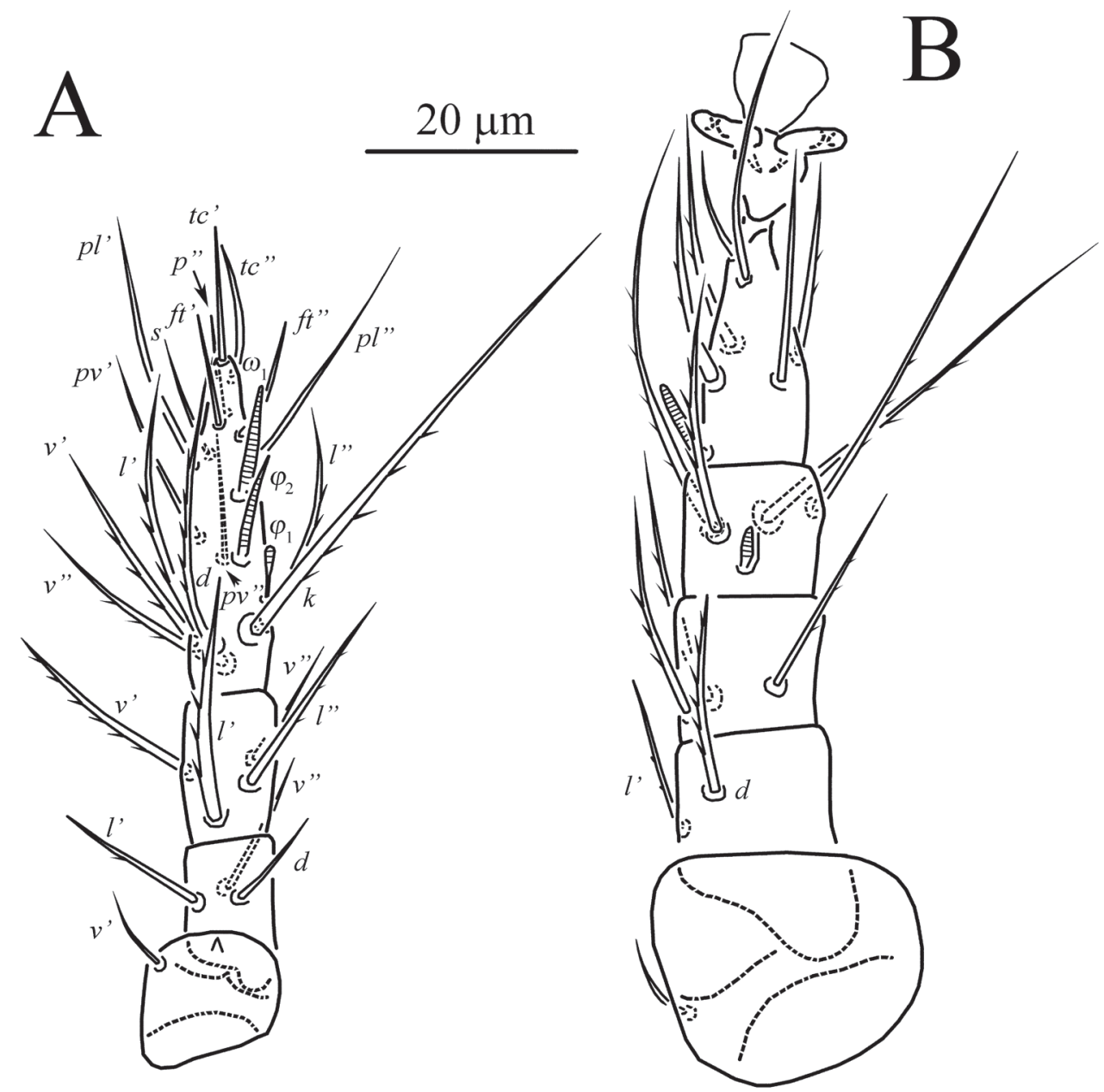

Figure 6. Caesarodispus samsinaki (Mahunka, 1967), comb. n., female: A leg I B leg II.

Male and larva unknown.

Material examined. One female, RUSSIA: Tyumen Province, vicinity of Tyumen, $57^{\circ} 04^{\prime} 03^{\prime \prime} \mathrm{N}, 65^{\circ} 04^{\prime} 12^{\prime \prime} \mathrm{E}$, on ants Formica rufa L., 17 August 2014, coll. A.A. Khaustov.

Distribution and hosts. This species was originally described from the Czech Republic (Mahunka 1967) where it was collected from ants Formica rufa. It was also recorded from Ukraine and Belarus (Sevastianov 1978). This is a new record for the fauna of Russia.

Remarks. Mahunka (1967) described this species in the genus Pygmephorus Kramer (Pygmephoridae). Later on, he replaced it to the genus Brennandania Sasa, 1961 (Microdispidae) (Mahunka 1972). Sevastianov (1978) placed this species in the genus Petalomium Cross, 1965 (Neopygmephoridae). 


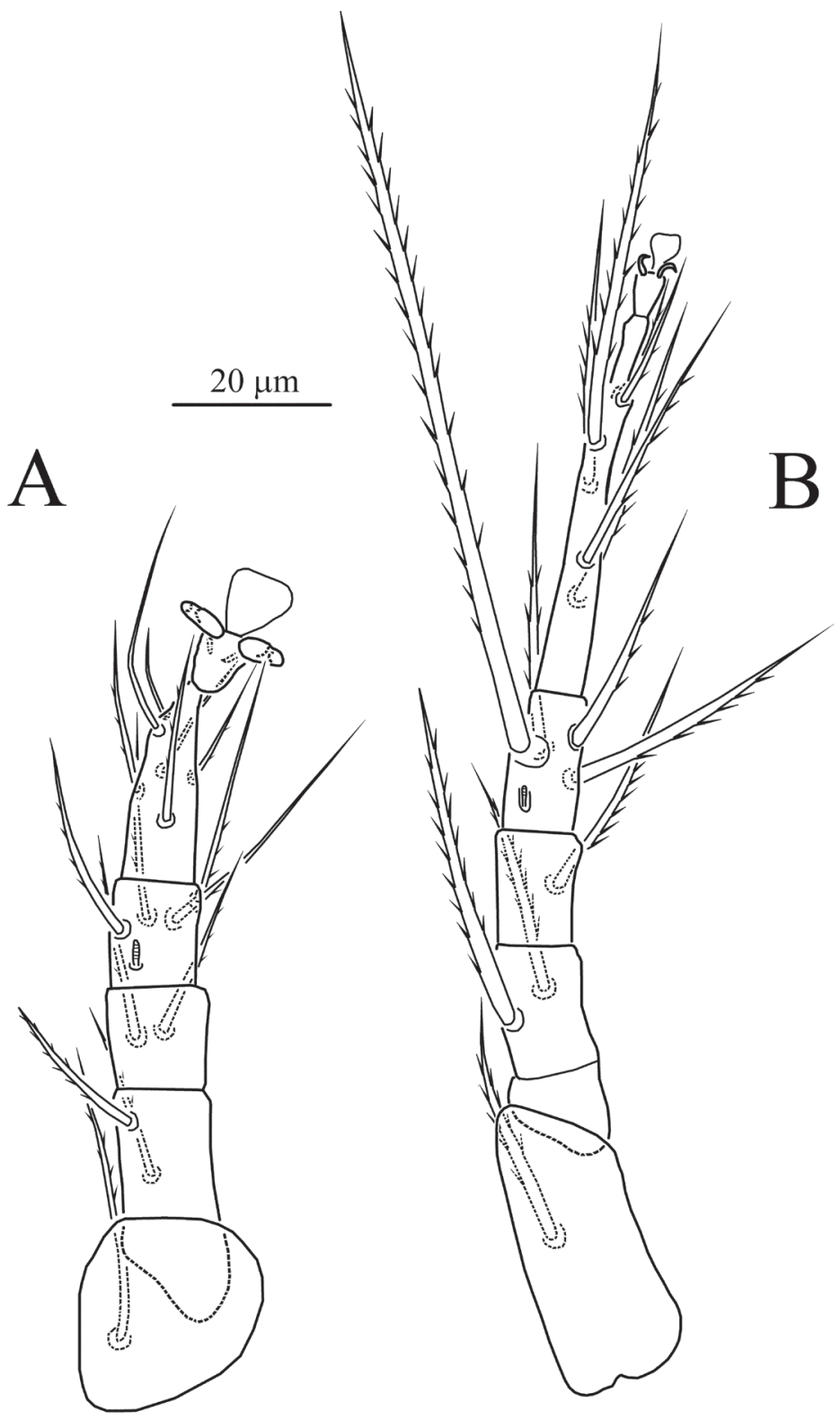

Figure 7. Caesarodispus samsinaki (Mahunka, 1967), comb. n., female: A leg III B leg IV.

According to key to families of the superfamily Pygmephoroidea provided by Khaustov and Ermilov (2011) this species undoubtedly belongs to the family Microdispidae by having three setae on femur I, unmodified seta $d F e I$ and presence of only one pair of setae on prodorsum. I placed this species in the genus Caesarodispus based on the following combination of characters: 1) tibiotarsus I without claw, 2) leg I distinctly shorter and thinner than leg II, 3) seta $s$ of tibiotarsus I present, 4) pharyngeal 
pumps 1 and 3 vestigial, pharyngeal pump 2 large, distinctly transversely striated, 5) posterior margin of posterior sternal plate entire. All of these characters well agree with diagnosis of the genus Caesarodispus.

Unlike other known species of the genus Caesarodispus, C. samsinaki has only two setae on femur II ( $v$ "absent) and only three solenidia on tibiotarsus I ( $\omega_{2}$ absent). However reduction of leg chaetotaxy was also recorded in C. klepzigi Khaustov and Moser, 2008, which has only two setae on femur I, while other Caesarodispus species have three setae.

The original description of C. samsinaki of Mahunka (1967) is incomplete, thus I made a redescription of this species. The present redescription of $C$. samsinaki is based on material from Western Siberia. The specimens from Western Siberia are well agreed with original description of C. samsinaki, especially having lanceolate dorsal idiosomal setae and unique reticulated hysterosomal tergites, and undoubtedly conspecific with it.

\section{Caesarodispus minutus (Sevastianov, 1981)}

Microdispus minutus Sevastianov, 1981, p. 28, fig. 5.

Caesarodispus minutus: Khaustov 2008: 390.

Material examined. Eleven females, Russia: Tyumen Province, Tyumen region, vicinity of settlement Narimanovo, $57^{\circ} 21^{\prime} 56^{\prime \prime} \mathrm{N}, 65^{\circ} 08^{\prime} 21^{\prime \prime} \mathrm{E}$, in the nest of ants Lasius flavus (Fabricius), 30 July 2014, coll. V.A. Stolbov.

This species was described from Ukraine from ants Tetramorium caespitum L. (Sevastianov 1981). Khaustov (2009) redescribed it based on type material. It was also recorded from Iran from Temnothorax sp. (Loghmani et al 2014). This is a new record for the fauna of Russia.

\section{Key to world species of the genus Caesarodispus (females)}

1 Hysterosomal tergites not reticulated, femur II with three setae. 2

- Hysterosomal tergites distinctly reticulated, femur II with two setae ( $v$ " absent)..... C. samsinaki (Mahunka, 1967), comb. n. Czech Republic, Ukraine, Belarus, Russia. On Formica rufa.

2 Seta $v$ ' of genu I not thickened, pointed. 3

- Seta $v$ 'of genu I distinctly thickened, widened distally, strongly barbed... .... C. pusillus Khaustov, 2009. Crimea. In the nest of Crematogaster schmidti Seta $d$ no more than 1.5 times longer than $f$......

- Seta $d$ about 4 times longer than $f$.....

C. klepzigi Khaustov \& Moser, 2008. U.S.A. On Solenopsis invicta Seta $d$ of tibia IV smooth or weakly barbed, not reaching beyond tip of pretarsus IV 
5 Seta $d$ of femur IV subequal to or longer than $t c$ " of tarsus IV

- $\quad$ Seta $d$ of femur IV more than 2 times shorter than $t c$ " of tarsus IV C. gaius Mahunka, 1977. France. On Myrmica sabuleti

6 Setae $d$ and $f$ lanceolate and strongly barbed

C. brevipes Mahunka, 1986. Hungary. In ant nest

- $\quad$ Setae $d$ and $f$ not lanceolate, weakly barbed.

C. modestus (Berlese, 1903). Italy, Russia (Crimea). On Messor spp.

7 Posterior part of aggenital plate smooth

8

- $\quad$ Posterior part of aggenital plate distinctly reticulated

C. shandizensis Loghmani \& Hajiqanbar, 2014. Iran. On Temnothorax sp. Setae $f$ distinctly longer than distance $f-f \ldots . . C$. minutus (Sevastianov, 1981).

Ukraine, Iran, Russia. On Tetramorium caespitum, Lasiusflavus, Temnothoraxsp. - $\quad$ Setae $f$ shorter than distance $f-f$.....

.... C. acuminatus (Sevastianov, 1981). Ukraine. On Tetramorium caespitum

\section{Acknowledgements}

The author thanks Dr. A.V. Tolstikov for valuable comments on the manuscript, Dr. V.A. Stolbov, S.A. Ivanov and V.M. Salavatulin for their help with collecting mites, D.V. Zhuravskiy (Tyumen State University, Russia) for help with SEM micrographs. This research was supported by the Ministry of Education and Science of the Russian Federation, project title "Myrmecophilous Acariform Mites (Acariformes) of the South of Western Siberia”, cooperative agreement No. 6.1933.2014/K.

\section{References}

Berlese A (1903) Diagnosi di alcune nuove specie di Acari italiani, mirmecofili e liberi. Zoologischer Anzeiger 27: 12-28.

Cross EA (1965) The generic relationships of the family Pyemotidae (Acarina: Trombidiformes). The University of Kansas science bulletin 45: 29-275.

Grandjean F (1944) Observations sur les Acariens de la famille des Stigmaeidae. Archives des Sciences Physiques et Naturelles 5, 26: 103-131.

Grandjean F (1947) L'origine pileuse des mors et la chaetotaxie de la mandibule chez les Acariens actinochitineux. Comptes rendus des séances de l'Academie des Sciences 224: 1251-1254.

Hajiqanbar H, Hosseininaveh F (2014) A new genus and species of the family Microdispidae (Acari: Prostigmata) associated with Oryctes nasicornis (Coleoptera: Scarabaeidae) and redescription of the monotypic genus Vietodispus Mahunka, 1975. Zoological Studies 53: 58-70. doi: 10.1186/s40555-014-0058-7

Kaliszewski M, Athias-Binche F, Lindquist EE (1995) Parasitism and parasitoidism in Tarsonemina (Acari: Heterostigmata) and evolutionary considerations. Advances in Parasitology 35: 335-367. doi: 10.1016/S0065-308X(08)60074-3 
Khaustov AA (2004) Mites of the family Neopygmephoridae Cross, 1965 stat. n. and their position in Heterostigmata. In: Balashov YS (Ed.) VIII Russian Acarological Conference, St.-Petersburg. Zoological Institute of RAS, St.-Petersburg, 137. [in Russian]

Khaustov AA (2008) Mites of the family Scutacaridae of Eastern Palaearctic. Akademperiodyka, Kiev, 291 pp.

Khaustov AA (2009) New and little known species of mites of the genus Caesarodispus (Acari, Heterostigmata, Microdispidae) associated with ants (Hymenoptera, Formicidae) from Ukraine. Vestnik Zoologii 43: 387-393. http://www.degruyter.com/view/j/vzoo.2009.43. issue-5/v10058-009-0017-7/v10058-009-0017-7.xml

Khaustov AA, Ermilov SG (2011) A new species of the genus Siteroptes (Acari: Heterostigmata: Pygmephoridae) from European Russia. Entomological Review 91(4): 528-532. doi: $10.1134 /$ S0013873811040178

Khaustov AA, Moser JC (2008) Two new species of mites of the genera Petalomium Cross and Caesarodispus Mahunka (Acari: Heterostigmata: Neopygmephoridae, Microdispidae) associated with Solenopsis invicta Buren (Hymenoptera: Formicidae) from the U.S.A. International Journal of Acarology 34: 115-121. doi: 10.1080/01647950808683714

Kurosa K (1979) Three new species of Unguidispus (Acari, Heterostigmata,Microdispidae) from Japan. Annotationes Zoologicae Japonenses 521: 63-71.

Lindquist EE (1986) The world genera of Tarsonemidae (Acari: Heterostigmata): a morphological, phylogenetic, and systematic revision, with a reclassification of family-group taxa in Heterostigmata. Memoirs of the Entomol. Society of Canada 136: 1-517. doi: 10.4039/ entm118136fv

Loghmani A, Hajiqanbar H, Talebi AA (2014) New species and new record of the genus Caesarodispus (Acari: Heterostigmatina: Microdispidae) phoretic on Temnothoraxsp. (Hymenoptera: Formicidae). Annales Zoologici 64(2): 273-278. doi: 10.3161/000345414X680627

Mahunka S (1967) Beiträge zur Kenntnis der Tschechoslowakischen Tarsonemini-Fauna. Věstník Československé společnosti zoologické 31: 240-244.

Mahunka S (1968) Xystrorostrum gen. n. und eine neue Siteroptes-art aus Ungarn (Acari). Reichenbachia 10: 127-131.

Mahunka S (1970a) Considerations on the systematic of the Tarsonemina and the description of new European taxa (Acari: Trombidiformes). Acta Zoologica Hungarica 16: 137-174.

Mahunka S (1970b) Beiträge zur Kenntnis der Milbenfauna der Ötztaler Alpen. 1. TarsoneminenArten aus der Umgebung von Obergurgl. Opuscula Zoologica (Budapest) 10: 271-289.

Mahunka S (1972) Tetủatkák - Tarsonemina (Magyarország állatvilága - Fauna Hungariae 110.) - XVIII. kötet, 16. füzet (Arachnoidea). Akademiai Kiado, Budapest, 215 pp.

Mahunka S (1977a) Neue und interessante Milben aus dem Genfer Museum XiX. Einige Angaben zur Kenntnis der Milbenfauna der Ameisen-Nester (Acari: Acarida, Tarsonemida). Archives des Sciences Geneve 30: 91-106.

Mahunka S (1977b) The examination of myrmecophilous tarsonemid mites based on the investigations of Dr. C. W. Rettenmeyer (Acari). Acta Zoologica Academiae Scientiarum Hungaricae 23: 99-132.

Mahunka S (1987) Tarsonemids of the Kiskunság National park (Acari). In: Mahunka S (Ed.) The fauna of the Kiskunság National park, 1. Akademiai Kiado, Budapest, 435-455. 
Sasa M (1961) New mites of the genus Pygmephorus from small mammals in Japan (Acarina: Pyemotidae). Japanese Journal of Experimental Medicine 31: 191-208.

Sevastianov VD (1969) New genus and species of mites of the Pyemotidae (Trombidiformes) family and their position in the family. Vestnik Zoologii 3: 66-71. [in Russian]

Sevastianov VD (1978) Tarsonemina. In: Ghilarov MS (Ed.) Opredelitel pochvoobitayushchikh kleshchey. Trombidiformes, Nauka, Moscow, 14-90. [in Russian]

Sevastianov VD (1981) New species of mites of the family Pygmephoridae (Tarsonemina, Trombidiformes). Vestnik Zoologii 6: 25-29. [in Russian] 